\title{
PRESIDENTIAL POWER TO GATHER INTELLIGENCE: THE TENSION BETWEEN ARTICLE II AND AMENDMENT IV
}

\author{
Philip A. Lacovara*
}

\section{INTRODUCTION}

Knowledge is power, and nowhere is this principle more diligently pursued than in the conduct of government, where the craft of intelligence has become both an art and a science. The collection of intelligence has no moral dimension as such. It takes on its coloration from the purposes for which the process is pursued, the manner in which the collection proceeds, and the uses to which the information is put. The combination of these factors and their shadings is almost endless. The development of intelligence has long been treated as an important aspect of statecraft, and intelligence can be used for legitimate or illegitimate objectives. The importance of effective intelligence in combating or conquering a foreign enemy on the battlefield was recognized 5,000 years ago in an ancient Chinese manual on warfare. Guarding against violent threats to the stability of a democratic society also requires informed vigilance. And a comprehensive domestic intelligence system is the skeleton of a totalitarian state.

\section{I}

\section{The Intelligence Function in} Our Constitutional System

In this paper, the focus is on the constitutional interests that bear on the collection of "foreign intelligence" within the United States. "Foreign intelligence" involves information used to conduct the foreign policy of the United States and to maintain its military security against potential aggressor nations. ${ }^{1}$ Only intelligence activities within the United States or directed at American citizens are analyzed, since the gathering of intelligence from foreign sources-and the conduct of covert operations frequently conducted by intelligence agencies-raise distinct problems more aptly treated as matters of diplomacy and policy than as issues of constitutional principle. In addition, al-

\footnotetext{
* Hughes Hubbard \& Reed, Washington, D.C.

1. In President Ford's Executive Order on United States Foreign Intelligence Activities, issued on February 18, 1976, "foreign intelligence" is broadly defined as "information... on the capabilities, intentions, and activities of foreign powers, organizations or their agents. . . Exec. Order No. 11,905, § 2(a)(1), 4 I Fed. Reg. 7704 (1976).
} 
though recognizing that federal and local law enforcement agencies also gather information about domestic criminal enterprises and about threats to "domestic security," the issues raised by such efforts will be discussed only to the extent that they relate to my primary focus: collection of foreign intelligence.

In the United States, the President bears primary responsibility for the scope and conduct of foreign intelligence activities, and his powers in this field are sweeping. The President's intelligence functions derive from his constitutional offices under article II of the Constitution as commander-in-chief of the armed forces, as sole organ of the nation in foreign relations, and as chief law enforcement officer. Because his powers are so broad and the responsibilities so sensitive, it is hardly surprising to find blunders and abuses in the exercise of these powers, either imputed to the President under the principle of accountability for activities of the executive branch, or traceable directly to a presidential judgment.

By now the problem is all too familiar: how to protect the national security while preserving domestic liberty. Watergate and the aftermath of sensational disclosures of the Government's disregard of the constitutional freedoms of American citizens in the name of protecting their safety have restored this dilemma-as old as the Republic itself ${ }^{2}$ - to the front pages. Many disclosures concerned the collection of information to which the Government was not entitled or that was amassed through improper techniques.

The Rockefeller Commission, investigating the Central Intelligence Agency, reported that for twenty years the CIA regularly intercepted mail between American citizens and residents of communist countries, despite the Agency's knowledge that the program contravened clear statutory language. ${ }^{3}$ By 1973, the mail-watch program had grown to the point that the New York interception unit, utilizing "watch lists" supplied in part by the Federal Bureau of Investigation, examined the outside of 2,300,000 pieces of mail, photographed 33,000 envelopes, and opened 8,700. ${ }^{4}$

The CIA's Operation CHAOS, expanding from an initial effort to monitor contacts with foreign governments and political groups by American citizens overseas, eventually compiled files on over 7,000 American citizens; the names of 300,000 Americans appeared in these files and were entered onto a computerized index. ${ }^{5}$

2. Abraham Lincoln, during our gravest national crisis, expressed the problem in these words: "Must a government, of necessity, be too strong for the liberties of its own people, or too weak to maintain its own existence?" I C. Sandburg, Abraham Lincoln, The War Years 296 (1939). See generally Note, Developments in the Law-The National Security Interest and Civil Liberties, 85 HaRv. L. Rev. $1130,1133-34$ (1972).

3. See Comm'n on CiA Activities Within the United States, Report to the President 101-15 (1975).

4. Id. at 20 .

5. Id. at 23 . 
SHAMROCK was the cover name of another information-gathering venture of dubious legality, this one under the auspices of the National Security Agency. In the thirty years of the program's existence, ${ }^{6}$ NSA and its predecessor agencies monitored much of this country's international cable traffic. By the 1960s, NSA, using sophisticated equipment, was able to monitor any telegram to, from, or mentioning individuals whose names appeared on its "watch list." In addition, the contents of many telegrams were funneled through NSA to other agencies of the Government. ${ }^{7}$

Nor has the FBI escaped unwanted notoriety. Longstanding rumors about "black bag jobs" and personal files of Director Hoover on elected officials have turned out to be true. Also, at the bidding of several presidents (of both political parties), the Bureau opened files on American citizens for the sole reason that they uttered ideas and sentiments at odds with then prevailing White House policy. ${ }^{8}$ Newspaper accounts also tell of the bugging of phones of the Mississippi Freedom Democratic Party and the covert electronic surveillance of the Reverend Martin Luther King, Jr. Critics of the Bureau ran the risk of subjecting themselves to similar treatment." Also on presidential orders, the Bureau participated in warrantless electronic surveillance of newspaper reporters ostensibly suspected by various presidents of being involved in leaks of classified information; the surveillance in at least one case clearly had nothing to do with such leaks. ${ }^{10}$

Finally, there was the Bureau's COINTELPRO program, which is worthy of mention even though it was not an information-gathering enterprise, because it illustrates the malign uses to which vast amounts of private information can be put with relative impunity. For example, as part of the COINTELPRO program, the FBI provided then Vice President Agnew with derogatory public record information and other allegations about Reverend Ralph David Abernathy, the President of the Southern Christian Leadership Conference, so that Agnew could "start destroying Abernathy's credibility." "1 Even after the supposed end of COINTELPRO, the FBI, with similar goals in

6. SHAMROCK was terminated by order of the Secretary of Defense on May 15, 1975. SHAMROCK is the subject of Memorandum from Staff of the Senate Select Comm. to Study Governmental Operations with Respect to Intelligence Activities submitted to the Senate Select Comm. on Intelligence. Nov. 6. 1975 (on file with the Senate Select Comm. on Intelligence).

7. Id.

8. This practice apparently dates back to the days of President Franklin Roosevelt, who ordered the FBI to make reports of "hundreds of persons who sent telegrams to the President that were-to quote the letter from the President's secretary to J. Edgar Hoover-'all more or less in opposition to the national defense, or that expressed approval of Colonel Charles Lindbergh's criticism of the President." 6 Political Abuse and the FBI: Hearings on S. Res. 21 Before the Select Comm. to Study Governmental Operations with Respect to Intelligence Activities, 94th Cong., Ist Sess. 471 (1975) (Exhibit 36).

9. Id. at 474 .

10. Id. at $479-80$.

11. Id. at 481-82. 
view, supplied a newsman with derogatory information about Daniel Ellsberg's lawyer and sent copies to the Attorney General, the Deputy Attorney General, and presidential aide H. R. Haldeman. ${ }^{12}$

The foregoing recitation, sadly, is only illustrative. It is not my present purpose to catalogue recently revealed abuses of the techniques of intelligence collection or the illicit uses to which such information can be put. In light of these events, however, one need not be an alarmist to express some fear for the safety of our constitutional liberties. Are our liberties, though perhaps diminished, nonetheless more secure because of governmental zeal in the name of national security? It is, of course, difficult to know, for as if by Orwellian logic, the perils from which we have been saved are too secret to reveal.

It would be irresponsible to deny that there are real and substantial reasons justifying-and even mandating-the gathering of secret intelligence. We know there are foreign powers who see their national interests as inimical to ours. We know that they have intelligence services actively at work probing our governmental processes and policies. In addition, some of our own citizens, for diverse reasons, see violence-sometimes savagely random and indiscriminate-as a permissible alternative to free speech in seeking social change. On the same morning that press accounts of the murderous La Guardia Airport bombing appeared, a senior FBI official was quoted as asking in an earlier interview: "Is the Constitution a suicide pact? Do we have to wait until the bomb goes off and people are killed or injured? Or can we act while the fuse is still sputtering?"13 And FBI Director Clarence Kelley, who is generally regarded as an enlightened police administrator, candidly expressed what many Americans, worried about crime and terrorism, may secretly feel: "We must be willing to surrender a small measure of our liberties to preserve the great bulk of them." 14

A threshold objection to that assertion is that it reflects a lack of sensitivity to the constitutional constraints on the Government's authority to force that surrender. The other flaw in that argument is that when people talk about willingly sacrificing some freedom to gain peace of mind and safety, they are likely to be thinking about someone else's freedom. Too often in human history we have seen the penchant for "law and order" carry a society down a slippery slope into airtight repression.

I think I am correct in suggesting that the logical justification behind some recent intelligence operations reflects a muddled teleology. Such logic resem-

12. Id.

13. Washington Post, Dec. 30, 1975, at 1, col. 4. The truism that the "constitution is not a suicide pact" was made, without apparent effect, by former Assistant Attorncy General for Internal Security Robert Mardian in the so-called "Keith" case, United States v. United States Dist. Court, 407 U.S. 297 (1972), dealing with domestic security wiretapping.

14. Washington Post, Dec. 30, 1975, at A4, col. 1 . 
bles that shown by the man who walked the streets of New York snapping his fingers, explaining he was keeping the elephants from stampeding; when some passerby had the temerity to comment that there were no elephants within thousands of miles, the fervent finger-snapper replied with intense satisfaction, "See, it works." His antics, of course, were merely silly. In contrast, we have the word of the then Attorney General that some of the recent intelligence operations conducted in the name of our national security were not only "foolish," but "outrageous" as well. ${ }^{15}$

Two broad areas of inquiry are suggested by the subject of the President's intelligence-gathering power. One concerns the range of legitimate uses of information gathered by the President and his subordinates. Among other problems here, one is concerned with record compilations such as data banks, where the ability to amass and correlate vast amounts of even public information has enhanced governmental resources, both for good and for mischief. There is also cause for concern about controlling the dissemination of such data and specifying the number of people with access to data and the purposes for which they could be used. Only recently has the law turned its attention to these problems; some examples of the results of that attention are the Privacy Act of $1974^{16}$ and the various decisions controlling the compilation and use of arrest records. ${ }^{17}$ Technological innovations have vastly expanded the ability of government to store, retrieve, and correlate enormous amounts of data about public figures and private citizens. The policy issues raised by this technology deserve careful and extended treatment, but they are beyond the scope of this paper.

A second area, and one to which I shall direct my attention, concerns the intelligence-gathering process itself. A few preliminary observations are in order. First, the most important constitutional provision relevant to the gathering of intelligence is the fourth amendment, which protects against "unreasonable" searches and seizures. But the fourth amendment is not an absolute protection of individual privacy; it simply places personal privacy onto a balance scale. Moreover, it does not circumscribe the areas into which, under the appropriate circumstances, the government may inquire. No par-

15. See 6 Hearings on S. Res. 21 Before the Select Comm. to Study Governmental Operations with Respect to Intelligence Activities, 94 th Cong., Ist Sess. 381 (1975) (Testimony of Edward H. Levi). That same day, Attorney General Levi made public his tentative guidelines, first submitted to the Senate Select Committee, defining the circumstances that would justify the FBI's conduct of "domestic security investigations" and describing the investigative "techniques" that could be used at different phases of the investigations. The guidelines would also regulate the dissemination of the resulting intelligence. A second draft of these guidelines was released by the Department of Justice on February 11, 1976. On that day, Attorney General Levi and FBI Director Clarence M. Kelley testified about the policies reflected in the proposed guidelines.

16. Pub. L. No. 93-579, 88 Stat. 1897 (codified at 5 U.S.C.A. $\$$ 552a (1975 Supp.)).

17. E.g., Tarleton v. Saxbe, 507 F.2d 1116 (D.C. Cir. 1974); Menard v. Saxbe, 498 F.2d 1017 (D.C. Cir. 1974). 
ticular information-gathering technique nor, for that matter, any subject of inquiry is forbidden to the Government solely because of the provisions of the fourth amendment. Of course, related interests protected primarily by other constitutional provisions-most particularly the first amendment speech and association protections and the fifth amendment ban on compulsory selfincrimination and guarantee of due process-are closely related to fourth amendment concerns; and, indeed, the Supreme Court has on occasion taken explicit note of these interests in fashioning fourth amendment rulings. ${ }^{18}$ For the most part, however, the central inquiry under the fourth amendment is not whether the Government may inquire into otherwise personal affairs, but when and how.

Second, as just suggested, various intelligence methods can raise issues under the first and fifth amendments, particularly when "domestic security" investigations rather than "foreign intelligence" operations are involved. These questions arise, for example, from the conduct of surveillance of even public or semipublic political meetings and rallies, or from the use of undercover agents, infiltrators, and agents provocateur. Some courts have held, or at least suggested, that aggressive or ill-founded observation or penetration of a group's activities by intelligence agents may impinge upon first amendment rights of free speech or free association. ${ }^{19}$ But the Supreme Court's decision in Laird $\%$. Tatum, ${ }^{2 "}$ holding that the constitutional claims raised there did not present a concrete "case or controversy," indicates that the judicial role in drawing constitutional lines in this area is likely to be quite limited. The Court has, moreover, rejected the argument that the activities of an undercover agent aiding suspects in pursuing illegal activities-in effect, serving as an agent provocateur-denied the suspects' due-process rights. ${ }^{21}$ Under all these

18. See, e.g., United States v. United States Dist. Court, 407 U.S. at 313-14: Boyd v. United States, 116 U.S. 616 (1886). Compare Rochin v. California, 342 U.S. 165 (1952), with Schmerber v. California, 384 U.S. 757 (1966) (due process may be violated by investigative techniques).

19. See, e.g., Socialist Workers Party v. Attorney General, 510 F.2d 253 (2d Cir. 1974) (invalidating injunction against FBI surveillance of radical political convention as unwarranted by record, but precluding FBI from transmitting names of attendees to Civil Service Commission), stay denied, 419 U.S. 1314 (1974) (Marshall, J.); Fifth Avenue Peach Parade Comm. v. Cray, 480 F.2d 326 (2d Cir. 1973) (FBI investigation of antiwar demonstration held not shown to have chilling effect on first amendment rights); Tatum v. Laird, 444 F.2d 947 (D.C. Cir. 1971) (surveillance by military intelligence held subject to first amendment challenge), rerid, 408 U.S. I (1972) (complaint ordered dismissed for lack of concrete case or controversy); Handschu v. Special Services Div., 349 F. Supp. 766 (S.D.N.Y. 1972) (holding that use of infiltrators and informants by New York City Police Intelligence Division did not itself involve constitutional deprivation, but also holding that abuse of such techniques, or encouragement to political groups to engage in crimes, or intent to chill first amendment rights would be unconstitutional); White v. Davis, 31 Cal. 3d 757, 533 P.2d 222, 120 Cal. Rptr. 94 (1975) (en banc) (holding that trial court could enjoin Los Angeles Police Department from "covert intelligence gathering at UCLA" as violation of "academic freedom" protected by first amendment, explaining that "the air of its classrooms would be befouled indeed by the presence of secret police").

20. Laird v. Tatum, 408 U.S. 1 (1972).

21. United States v. Russell, 411 U.S. 423 (1973). Other forms of intelligence gathering re- 
circumstances, I believe the fourth amendment is the primary operative feature of the Constitution bearing on the President's collection of secret intelligence.

Third, "privacy" within the meaning of the fourth amendment is a unitary concept, and information is either within the zone of privacy or it is not. The courts do not enforce any person's expectations that his actions will be kept private for some purposes but not for others. Thus, for example, the Supreme Court has held that the use of informers and infiltrators is generally not covered by the fourth amendment ${ }^{22}$ since, in confiding to an apparent friend or compatriot-who turns out to be a government agent-the person has chosen not to keep his affairs totally private. So also, the use of government personnel to monitor "public" events-demonstrations or political meetings, for example-may raise other legal and political questions, but under present doctrine, at least, no questions of fourth amendment law. ${ }^{23}$

Fourth, the impact of judicial construction of the fourth amendment upon intelligence activities may be surprisingly narrow. Judicial opportunity to measure government conduct against the standards of the fourth amendment comes primarily in the context of criminal prosecutions where the accused seeks to have incriminating evidence excluded as tainted by illegal government methods. ${ }^{24}$ Thus, as some FBI and CIA surveillance programs suggest, public officials may choose to engage in deliberate violations of the fourth amendment in gathering intelligence. Since criminal prosecutions are at most a secondary objective, the impact of the "exclusionary rule" is a largely illusory deterrent.

In the national security area, then, the judicial role may be quite limited, and indeed almost peripheral. To the extent the inquiry focuses on the judicial function, the results may be somewhat distorted, and consequently we may perhaps tend to overestimate the extent to which the judiciary can protect us. Controversy over the extent of the judicial role in authorizing electronic surveillance ${ }^{25}$ for intelligence related to foreign affairs illustrates the point.

cently depicted in congressional testimony raise moral questions that are difficult to classify as having any constitutional dimension-such as the alleged instructions by the FBI to an informant within the Ku Klux Klan to engage in adulterous affairs with the wives of Klan members to pick up potentially interesting information and to fornent discord. 6 Hearings on $S$. Res. 21 Before the Select Comm. to Study Governmental Operations with Respect to Intelligence Activities, 94th Cong., Ist Sess. 118 (1975) (Testimony of Gary Thomas Rowe).

22. See United States v. White, 401 U.S. 745 (1971); Hoffa v. United States, 385 U.S. 293 (1966).

23. Katz v. United States, 389 U.S. 347 (1967).

24. In some circumstances, however, parties who deem themselves injured by illegal searches and seizures may seek damages for their injuries. See Bivens v. Six Unknown Named Agents, 403 U.S. 399 (1971).

25. Since the issue has almost always arisen in the context of electronic surveillance, one could 


\section{The Present State of the Law: Uncertain}

In United States \%. United States District Court, ${ }^{26}$ the so-called "Keith" case, ${ }^{27}$ the Supreme Court was called upon to review the validity of a wiretap that had been installed at the direction of the Attorney General ${ }^{28}$ to gather information about militants whose plans were thought to present a danger of sparking domestic violence. The Court held that the fourth amendment requires the issuance of a warrant prior to initiation of electronic surveillance directed at domestic individuals or organizations, even when it is believed that their activities constitute a direct threat to national security. Although this was surely a landmark decision, the Court was quite explicit in limiting the reach of its holding. At least twice in the course of Justice Powell's opinion for the Court, he emphasized that the Court was not implying an answer to the separate question of whether the Constitution requires prior judicial approval where surveillance relates to activities colored by the involvement of a foreign power, either directly or indirectly. ${ }^{29}$ In so limiting its holding, the Court followed cautiously upon a path marked out a few years earlier in Katz $\%$. United States, ${ }^{31}$ in which the Court first held that the fourth amendment applies to interceptions of telephone communications. ${ }^{31}$ In $\mathrm{Katz}$, the Court first expressed the view that the necessity of prior judicial authorization in situations involving "national security" was very much an open question. ${ }^{32}$

Where "foreign intelligence" is involved, the question remains without Supreme Court resolution, but "Keith" laid to rest the issue as it relates to

conclude that, under Katz v. United States, 389 U.S. 347 (1967), other forms of surveillance, surreptitious entry, for example, are subject to identical constraints. But Kaiz held only that the fourth amendment was violated by warrantless interception of a conversation in the course of normal criminal investigation, and it does not necessarily follow that warrantless physical entry is constitutional whenever warrantless electronic surveillance would be lawful. Indeed, in United States v. Ehrlichman, 546 F.2d 910 (D.C. Cir. 1976), the Government argued that whatever the proper resolution of the question as to the necessity for prior judicial approval for electronic surveillance, the fourth amendment has always prohibited all warrantless entries, absent exigent circumstances, whatever the justification. Brief for the United States (filed May 2, 1975).

26. 407 U.S. 297 (1972)

27. The Hon. Damon J, Keith, of the Eastern District of Michigan, was the district judge whose orders were reviewed in the proceeding.

28. Beginning with President Franklin D. Roosevelt, successive presidents had authorized their attorneys general to exercise what was asserted to be the President's power to conduct warrantless electronic surveillance of suspected subversives.

29. 407 U.S. at $308,321-22$.

30. 389 U.S. 347 (1967)

31. Katz overruled a contrary determination in Olmstead v. United States, 277 U.S. 438 (1928), a case famous not only for its holding that the fourth amendment reached only physical trespasses, but also for Justice Brandeis's prescient and eloquent dissent about the dangers of overzealous law enforcement.

32. 389 U.S. at 358 n.23. 
domestic threats to the national security. Acknowledging that the ultimate test of a search under the fourth amendment is "reasonableness," the Court pointed out that the warrant clause of the fourth amendment has been interpreted to supply a presumption that warrantless searches are unreasonable and therefore unconstitutional, except in exigent circumstances. ${ }^{33}$ That the President, as well as his delegate, the Attorney General, has a constitutional obligation to protect the nation's internal security was unquestioned; similarly acknowledged was the propriety of the wiretap technique. But the Court confessed apprehension about its use, particularly in the area of political crimes, where the values protected by the fourth amendment converge with those protected by the first amendment: ${ }^{34}$

History abundantly documents the tendency of Government-however benevolent and benign its motives-to view with suspicion those who most fervently dispute its policies. Fourth Amendment protections become the more necessary when the targets of official surveillance may be those suspected of unorthodoxy in their political beliefs. The danger to political dissent is acute where the Government attempts to act under so vague a concept as the power to protect "domestic security". . . The price of lawful public dissent must not be a dread of subjection to an unchecked surveillance power. Nor must the fear of unauthorized official eavesdropping deter vigorous citizen dissent and discussion of Government action in private conversation. For private dissent, no less than open discourse, is essential to our free society.

The Court concluded that first and fourth amendment freedoms could not be guaranteed in this area without a warrant requirement. Embodied in the fourth amendment, it reasoned, is the firm policy that the neutral and detached judgment of the magistrate is essential in determining whether a search is appropriate under the circumstances presented.

In reaching this conclusion, the Court rejected claims by the Government that imposition of a warrant requirement could endanger the national security. ${ }^{35}$ The Court did not describe the circumstances under which a warrant may issue-in doctrinal terms, the meaning of "probable cause"-in the national security context. As discussed below, it is analytically a fundamental error to address the question whether judicial approval of an intelligence surveillance is required without reference to the criteria upon which approval must be granted or withheld. Nevertheless, since "Keith," the Justice Department has reportedly obtained warrants for national security searches, but on what criteria is not known.

33. 407 U.S. at 314-17. The fourth amendment provides:

The Right of the People to be secure in their Persons, Houses, Papers, and Effects, against unreasonable Searches and Seizures, shall not be violated, and no Warrants shall issue, but upon probable Cause, supported by Oath or Affirmation, and particularly describing the Place to be searched, and the Persons or Things to be seized.

34. 407 U.S. at 314

35. Similar arguments are discussed infra at pp. 117-119. 
Since "Keith," three courts of appeals have considered the question left open in that decision-whether a judicial warrant is constitutionally necessary where a search is conducted ancillary to the President's management of the nation's foreign affairs and his maintenance of its security against foreign powers. In the first case, United States v. Brown, ${ }^{36}$ the Court of Appeals for the Fifth Circuit, relying on an earlier pre-"Keith" decision, ${ }^{37}$ concluded after little discussion that the President has search authority unconstrained by the warrant clause of the fourth amendment. That authority, the court held, is derived from the President's inherent power to conduct the nation's foreign affairs and was sufficient to permit the warrantless tapping of telephone calls to a foreign embassy. Somewhat more extended analysis produced the same conclusion in United States $\%$. Butenko. ${ }^{38}$ There, the Court of Appeals for the Third Circuit in an espionage case considered the lawfulness of a tap on a Russian national working at the United Nations. While acknowledging the generally salutary effects of a warrant requirement, the court held that because extreme prejudice to the national interest could result from an improvident rupture in the conduits of information necessary for informed foreign policy-making, the warrant requirement should not be applied to the gathering of foreign intelligence. ${ }^{39}$

A different result emerged when the issue was presented in a different context in Zweibon $\%$. Mitchell, ${ }^{40}$ decided by the Court of Appeals for the District of Columbia Circuit. This was a civil action brought by members of the Jewish Defense League, whose phones had been tapped without warrants, seeking damages from the Attorney General and other officials. The Department of Justice maintained that warrantless taps were proper because the JDL's activities included anti-Soviet demonstrations and harassment of Soviet diplomats while in the United States, and thus had a direct effect on foreign policy. In addition, the Government argued its concern about the possibility of retaliatory measures from the Soviets, which might subject American lives and property abroad to a danger of foreign attack.

The case produced six separate opinions. To oversimplify a bit: Five, possibly six, judges ${ }^{41}$ held that the warrantless surveillance violated the Constitution because the parties whose phones were tapped were not foreign govern-

36. 484 F.2d 418 (5th Cir. 1973), cert. denied, 415 U.S. 960 (1974).

37. United States v. (Cassius) Clay, 430 F.2d 165 (5th Cir. 1970), rev'd on other grounds, 403 U.S. 698 (1971).

38. 494 F.2d 593 (3d Cir.) (en banc), cert. denied sub nom. Ivanov v. United States, 419 U.S. 881 (1974)

39. The court, however, did hold the fourth amendment fully applicable to such searches and emphasized that the reasonableness of such searches is subject to post hoc judicial review, albeit under a liberalized standard of probable cause.

40. 516 F.2d 594 (D.C. Cir. 1975).

41. Judge Mackinnon's opinion is not altogether clear on how he would resolve the constitutional issue. 
ments or agents, nor their collaborators; two judges found the surveillance improper on statutory grounds. ${ }^{42}$ Apparently, Judges Wilkey and Mackinnon would hold, were the question directly presented, that warrantless searches of foreign governments, agents, and their collaborators are valid under the fourth amendment; but the reasoning of the plurality, expressed in a careful and scholarly opinion by Judge Wright, would forbid warrantless searches of any kind, absent exigent circumstances delineated in already established law.

The Department of Justice did not seek review of the Zweibon decision, in part because previous attempts to secure Supreme Court review of the issue had proved unavailing. ${ }^{43}$ Another reason for not seeking Supreme Court review apparently was the judgment that the decision, viewed narrowly, conformed to Department policy, at least as currently defined.

The Government's present policy has recently been described publicly and in detail. According to testimony by then Attorney General Edward H. Levi, warrantless electronic surveillance is conducted only in narrowly defined cases, upon the personal approval of the Attorney General. Attorney General Levi reported that requests ${ }^{44}$

... are only authorized when the requested electronic surveillance is necessary to protect the nation against actual or potential attack or other hostile acts of a foreign power; to obtain foreign intelligence deemed essential to the security of the nation; to protect national security information against foreign intelligence activities; or to obtain information certified as necessary for the conduct of foreign affairs matters important to the national security of the United States. In addition, the subject of the electronic surveillance must be consciously assisting a foreign power or foreign-based political group, and there must be assurance that the minimum physical intrusion necessary to obtain the information sought will be used.

Requests must first be reviewed by the $\mathrm{FBI}$, be approved in writing by the Director, and must set forth the relevant circumstances purporting to justify

42. Title 11I, $\S \S 801-02$ of the Omnibus Crime Control and Safe Streets Act of 1968, Pub. L. No. 90-351, 82 Stat. 211 (codified at 18 U.S.C. $\$ \S 2510-20$ (1970)), details procedures for the interception of wire or oral communications. Section 2511 proscribes such interception "[e]xcept as otherwise specifically provided in this chapter." But section $2511(3)$ disclaims any congressional intent to

limit the constitutional power of the President to take such measures as he deems necessary to protect the Nation against actual or potential attack or other hostile acts of a foreign power, to obtain foreign intelligence information deemed essential to the security of the United States, or to protect national security information against foreign intelligence activities.

Judge McGowan concluded that the facts involved in Zweibon presented "no situation falling with the Congressional disclaimer," 516 F.2d at 618 (McGowan, J., concurring), and that therefore the surveillance was unlawful under Title IIl. Judge Robb agreed. 516 F.2d at 688 (Robb, J., concurring).

43. Certiorari was denied in both the Brown and Butenko cases, even though the Department of Justice acquiesced in the petition to review Butenko because of its desire to speed resolution of the issue.

44. 5 Hearings on S. Res. 21 Before the Select Comm. to Study Governmental Operations with Respect to Intelligence Activities, 94th Cong., 1st Sess. 70-71 (1975) (Statement of Edward H. Levi). 
the surveillance, including the name of the presidential appointee initiating the request. ${ }^{45}$

This, then, is how the law stands: The Supreme Court has not resolved the issue whether warrantless surveillance in matters of "foreign intelligence" offends the fourth amendment or constitutes an exceptional presidential power unaffected by the warrant clause. The President asserts that his role as the chief foreign affairs organ of government does not require him to seek warrants, but that this power is allegedly exercised with circumspection and restraint. The lower federal courts seem willing to recognize the President's constitutional claim, at least where the object of the intelligence operation is a foreign embassy or suspected foreign agent. Less certain is whether the courts will construe this "foreign intelligence" power as broad enough to encompass domestic groups whose views and acts may have an impact on foreign relations. But these issues are still in ferment, and there are thought-provoking arguments on both sides.

III

The Arguments About Presidential Prerogatives:

INCONCLUSIVE

\section{A. Doctrinal}

Doctrinal arguments can be disposed of quickly, for although they always inform a result, in this area they do not compel one. We could hardly suppose that the Supreme Court would consider the implications of prior doctrine, developed in different contexts, as compelling a narrow view of the President's power if the Justices considered that result truly dangerous to the national security. On the other hand, it is equally unlikely that the Court would hold that the Constitution gives the President unfettered discretion to impinge upon the most precious liberties of American citizens simply to serve the expediency of foreign relations.

Both sides draw strength from two strands of doctrine, one concerning the fourth amendment, and the other bearing on presidential power over the conduct of foreign affairs. The case law under each strand can be read to support either side. As to the fourth amendment, proponents of warrantless searches argue that, as the Supreme Court has repeatedly recognized, ${ }^{46}$ the

45. Although these guidelines reserve to the President, acting through the Attorney General, the power to conduct warrantless surveillances, the Justice Department, in papers filed in a pending litigation, reports that in at least one recent instance the Attorney General has sought and obtained a warrant under circumstances that, under the guidelines, would not require him to do so. See Szulc v. Ehrlichman, Civil No. 74-1055 (D.D.C., filed Dec. 12, 1975). As discussed below, the Attorney General has recently recommended that Congress establish procedures for the issuance of judicial warrants even in foreign intelligence cases. See text at note 85 infra.

46. See, e.g., United States v. Edwards, 415 U.S. 800, 807 (1974). 
ultimate fourth amendment test of the constitutionality of a search is its "reasonableness" and that in some cases even the relative ease with which a search warrant could have been obtained does not render a warrantless search unreasonable. ${ }^{47}$ Surely, it is argued, it is imperative for the President to obtain foreign intelligence, and the President's judgments about the imperatives of foreign relations and military security are to be presumed to be "reasonable." Thus, since the ultimate determination of reasonableness is primarily the President's, the fourth amendment is satisfied without the necessity for prior judicial approval.

Proponents of a warrant requirement distinguish those cases in which the Supreme Court has apparently stated that the reasonableness of a search can be assessed without regard to the warrant clause ${ }^{48}$ and point instead to what is apparently the prevailing doctrine that "except in certain carefully defined classes of cases, a search of private property without proper consent is "unreasonable' unless it has been authorized by a valid search warrant."49

Arguments of similar generality are implied from those few Supreme Court cases that touch upon the President's foreign affairs powers and upon his powers as commander-in-chief and chief law enforcement officer. A common sentiment running throughout the cases from which proponents of presidential power draw strength is the oft-repeated statement that foreign policy judgments are essentially political, beyond the power or the competence of the judiciary to review. The nation must have one spokesman, it is argued, and it must be the President. ${ }^{50}$ The implication is that the President must decide what information he needs to discharge these responsibilities and how to obtain it, and a court may not interpose itself in that process. True, comes the reply, but no case has dealt with the specific issue of presidential authority to order warrantless surveillance, and several have stated that the President must exercise his foreign affairs powers, broad as they doubtless are, within constitutional limits. ${ }^{51}$

47. Id. (search of prisoner's clothes after jailing upheld despite absence of warrant); $c f$. Wyman v. James, 400 U.S. 309 (1971) (welfare recipients may be forced to submit to warrantless inspections of their homes as a condition to continued receipt of benefits).

48. Thus, Edwards, for example, can be distinguished on the ground articulated in Justice Powell's concurring opinion in United States v. Robinson, 414 U.S. 218, 237 (1973), that once placed in police custody, a suspect relinquishes virtually all legally cognizable interests in the privacy of his person. Wyman can be distinguished on the basis of the Court's alternative holding that what was involved was not legally a "search."

49. Camara v. Municipal Court, 387 U.S. 523, 528-29 (1967). See also Coolidge v. New Hampshire, 403 U.S. 443, 454-55 (1971). For a more complete exposition of this doctrinal swordplay, see Zweibon v. Mitchell, 516 F.2d 594, 628-33 (D.C. Cir. 1975).

50. See, e.g., Chicago \& Southern Air Lines, Inc. v. Waterman Steamship Corp., 333 U.S. 103, 111 (1948); United States v. Belmont, 301 U.S. 324 (1937); United States v. Curtiss-Wright Export Corp., 299 U.S. 304 (1936).

51. See, e.g., Youngstown Sheet \& Tube Co. v. Sawyer, 343 U.S. 579 (1952) (the so-called "Steel Seizure Case"); United States v. Curtiss-Wright Export Corp., 299 U.S. 304, 320 (1936). 
The Japanese relocation case, Korematsu $\%$. United States, ${ }^{52}$ still stands as the high-water mark of judicial deference to the executive's determination of expedient necessity, although Justice Black's opinion was at least careful to note that the Court's deference was based on the exceptional circumstance that "when under conditions of modern warfare our shores are threatened by hostile forces, the power to protect must be commensurate with the perceived danger." ${ }_{53}$ The Steel Seizure case ${ }^{54}$ indicates that any special presidential power for emergency conditions will be tolerated only in the most extreme circumstances and only when the Court itself is convinced that the danger is real and immediate. The Pentagon Papers case ${ }^{55}$ in part reflects this same sense of judicial independence.

The result is a doctrinal stand-off. As to both the fourth amendment and the foreign affairs issues, the positions of the contenders do not really clash; indeed, they are to each other as light to shadow-only when they stand together does the illuminated image take on recognizable form. The ultimate standard under the fourth amendment is, indeed, reasonableness, but recent cases, and most particularly "Keith," demonstrate a clear constitutional preference for warrants unless insistence on their utilization would "unduly frustrate the efforts of Government to protect itself." ${ }^{56}$ And while it is true that the President has broad powers in the field of foreign affairs, they must, of course, be exercised within constitutional limits. Thus, the strands of doctrine merely pose questions: Even assuming a fourth amendment preference for prior judicial approval of a search, is this a case where the preference is overridden by other factors? And even granting the obvious proposition that the President's foreign affairs powers are confined by the commands of the Constitution, what does the Constitution command? It should come as no surprise that the answer to these questions is likely to come from an assessment of the practical impact of either the imposition of a warrant requirement or of its absence. Yet, upon close examination one finds, I suggest, that the practical consequences of the answer to that question are surprisingly small.

\section{B. Practical Concerns}

Five principal arguments are arrayed against the imposition of a warrant requirement upon searches in the foreign relations/military security area. First, it is asserted that in foreign intelligence matters, speed is of the essence and that the extra time necessary to secure a warrant may spell the difference between a successful intelligence operation and a failure. This argument has

52. 323 U.S. 214 (1944).

53. Id. at 220 .

54. Youngstown Sheet \& Tube Co. v. Sawyer, 343 U.S. at 579.

55. New York Times Co. v. United States, 403 U.S. 713 (1971).

56. 407 U.S. at 315 . 
little to commend it, for established fourth amendment doctrine already recognizes that warrantless searches may lawfully be conducted where speed is of the essence. ${ }^{57}$ Moreover, given the elaborate Department of Justice procedures for approval of electronic surveillance quoted above, ${ }^{58}$ one must question whether an application for an ex parte warrant would add much time.

Little more substantial is the argument that warrant application proceedings might compromise secret information. The Court's disposition of the argument in "Keith" is directly on point and needs no refinement to be applied to searches in aid of the nation's foreign affairs. The Court noted that a warrant application is merely an ex parte request before a judge, and "[w]hatever security dangers clerical and secretarial personnel may pose can be minimized by proper administrative measures, possibly to the point of allowing the Government itself to provide the necessary clerical assistance." 59 In addition, it should be pointed out that the government has often presented top secret information to the courts for in camera examination, and I am not aware of a single leak attributed to the judical branch. In light of the recent history of the executive and legislative branches, it strikes me as almost disingenuous to suggest that it is the courts that cannot keep secrets.

Recently, the Department of Justice has asserted, as one reason for dispensing with a warrant requirement, that since applications will be sporadic and often not before the same judge, and since no opinion could be published, a requirement of prior judicial approval would hamper the development of this area of the law. ${ }^{60}$ While it may well be that development of the law in this area will not come about primarily through the medium of judicial interpretation, ${ }^{61}$ this hardly argues very strongly against a warrant requirement. It cannot be argued that "the law" in this area would grow any more rationally and vitally if the courts had no role in decision-making and if the interpretation of the fourth amendment involved exclusively executive deliberations.

A similar argument is made with respect to accountability. It is asserted that a warrant requirement would diffuse accountability, that officials of the executive branch would be insulated from scrutiny because they would always be able to deflect public concern onto the authorizing judge. This could occur; but there is no reason why it must-particularly if it is understood that the magistrate must largely depend on the representations of those officials who come before him. In fact, however, as discussed below, I believe that warrants would help fix, rather than diffuse, accountability.

57. See, e.g., Coolidge v. New Hampshire, 403 U.S. 443, 454-55 (1971).

58. See text at note 44 supra.

59. 407 U.S. at 321

60. Szulc v. Ehrlichman, Civil No. 74-1055 (D.D.C., filed Dec. 12, 1975).

61. See text at notes 83-87 infra. 
Finally, we come to the weightiest argument against a warrant requirement - that because of the complexity of the facts, many of which cannot be revealed, a judicial officer lacks the expertise necessary to decide whether to authorize a search. This argument was firmly rejected in the "Keith" case in the context of "domestic" surveillance, ${ }^{62}$ and by Judge Wright's opinion in Zweibon in a somewhat larger context. ${ }^{63}$ Although these courts are, I think, correct in concluding that the "judicial expertise" argument is ultimately unconvincing, their reasoning fails to persuade, because of what seems to me to be a fundamental methodological error.

Simply stated, how can one assert that a person is a qualified decisionmaker before he understands precisely what that person will be called upon to decide? The fourth amendment requires that no warrants be issued except "upon probable cause," but the amendment does not specify the necessary object of that "probable cause": In other words, probable cause to believe what? In the normal criminal context, law enforcement personnel must demonstrate that there is probable cause to believe that a proposed search will uncover evidence of a crime or the fruits or "instrumentalities" thereof. ${ }^{64}$ In certain situations, however, the Supreme Court has permitted judicial authorization for a search to turn on a more generalized inquiry. Thus, for example, in Camara v. Municipal Court, ${ }^{65}$ the Court permitted regulatory searches of dwellings to insure compliance with housing codes to be conducted "if reasonable legislative or administrative standards for conducting an area inspection are satisfied with respect to a particular dwelling" ${ }^{66}$ - that is, upon demonstration that the building to be searched is of the general type that the legislature authorized to be inspected. ${ }^{67}$

Drawing on this doctrine, the Supreme Court in "Keith" invited Congress to consider standards under which an intelligence warrant might be granted that could differ from those in ordinary criminal cases. Citing Camara, the Court noted that "[d]ifferent standards may be compatible with the Fourth Amendment if they are reasonable both in relation to the legitimate need of Government for intelligence information and the protected rights of our citizens. ${ }^{68}$ Hardly a definitive formulation of a rule of law, this cue was followed by the Zueibon plurality in similarly skirting the issue, as Judge Wright saved

62. The Court could hardly have been more emphatic: "If the threat is too subte or complex for our senior law enforcement officers to convey its significance to a court, one may question whether there is probable cause for surveillance." 407 U.S. at 320 .

63. 516 F.2d at $641-47$.

64. See, e.g., FED. R. CRIM. P. 41.

65. 387 U.S. at 538.

66. Id.

67. See also Almeida-Sanchez v. United States, 413 U.S. 266 (1973) (Powell, J., concurring): United States v. Martinez-Fuerte, 428 U.S. 543 (1976) (upheld validity of "area warrants" for Border Patrol to search randomly selected cars near border for illegal aliens).

68. 407 U.S. at $322-23$. 
for another day the attempt to define standards for issuance of warrants. ${ }^{69}$

To be sure, there is wisdom in the judicial practice of reserving for the future those questions that do not require immediate resolution. There is some doubt, however, whether the question "who decides" can meaningfully be divorced so neatly from questions about the appropriate standard for decision. An example will illustrate.

Assume the situation in which our Government desires to eavesdrop on conversations in the embassy of a potentially hostile power, and the Department of Justice decides to seek a warrant. Obviously, the object of the surveillance is not to gather evidence of a crime or the fruits or instrumentalities of a crime. The ordinary concepts of fourth amendment doctrine are simply irrelevant, since the warrant requirement and the "probable cause" standard itself evolved in the context of criminal investigations. In an intelligence operation, however, information is sought for reasons of state ordinarily unrelated to any criminal investigation.

What, then, is the question to be resolved by the magistrate? Must he determine merely that there is probable cause to believe that "useful" intelligence information will be acquired? How is he to know what is "useful"? And how can the intelligence authorities make a showing of "probable cause" that has any concrete content when a common technique of intelligence gathering is to scoop up comprehensive data from apparently worthy sources and only upon later analysis to learn what-if anything-has been illuminated. In traditional fourth amendment principles, the productivity of a search cannot serve as a retroactive validation for the absence of meaningful probable cause at the outset. Yet, application of such a standard for intelligence operations might forbid virtually all but the smallest fraction of those operations.

Perhaps the magistrate need determine only that there is probable cause to believe that our Government is dealing with a matter implicating foreign affairs. The $Z$ weibon case, however, suggests that an attenuated foreign-affairs link, even if potentially significant in practical terms, does not justify special treatment under the fourth amendment. What level of "probability" can prudently be demanded, and how can a magistrate evaluate the political predictions of statecraft: Must he determine that the government whose embassy is about to be electronically invaded is indeed hostile, or that its activities pose a threat to the security of the United States? Must our Government demonstrate a connection between the external threat and the information that it seeks? The questions are endless and imponderable.

Yet, if we do not know what the magistrate is to decide, how can it be determined that he is fit to decide it? If, for example, all that must be ascertained is that there is probable cause to believe that the persons to be

69. 516 F.2d at 646. 
searched are officials or agents of a foreign government, there is little cause to be concerned that such a determination is beyond the ken of a judicial officer. But by the same token, there is little reason to insist that such objective data be screened by a neutral magistrate. If, on the other hand, the magistrate must decide whether there is probable cause to believe that the information to be retrieved will relate to a threat to the security of the United States, there may be reason to fear lest the judgment of a magistrate override that of the President. These questions are not merely "procedural"; they involve judgments as to the very substance of the fourth amendment and the President's powers under article II, since a determination that the executive is to address its showing to a particular question is an acknowledgment that a search supported by only that determination is lawful.

IV

\section{Some Substantive Standards}

It would be unfair to me to fault the courts for failing to address an issue and then to forego the opportunity myself, so I will make a tentative effort. A two-pronged inquiry will, I believe, prove to be relatively simple to apply and certainly within the judicial ken. A magistrate first must determine the identity of the party or the premises to be searched. If the subject of surveillance is to be an official of a foreign government or political organization or their agent, or the premises of such a person, then the Attorney General need only produce evidence supplying probable cause to establish that fact. Thus, in the hypothetical about the foreign embassy, the Government would have to produce only that evidence necessary to demonstrate that there was probable cause to believe that the premises to be searched are under the control of a foreign government. Judgments as to the wisdom and propriety of searching officials or quarters of foreign powers are essentially political, not constitutional, and as to these, a judicial officer has little to offer. Should foreign governmental personnel and their effects be wrongly searched, the effect will be primarily diplomatic. This is not to suggest that such activities are invariably wise or proper, but that they do not directly threaten our liberty. To use the test for applicability of the fourth amendment that was articulated in Katz, foreign officials have little "reasonable" expectation of privacy;" instead, subjection to intelligence operations is a risk knowingly assumed by persons entering the service of one nation in the territory of the other. The magistrate's function would simply be to ascertain that there is cause to believe the object of surveillance fits into that category, with nothing more required.

Where private individuals are involved, whether they are Americans or

70. 389 U.S. 347, 361 (1967) (Harlan, J., concurring). 
foreign nationals, ${ }^{71}$ possible threats to individual liberty require a more stringent standard. The Attorney General, I would suggest, must show that there is probable cause to believe that an intelligence operation-either an electronic surveillance or a surreptitious entry-will uncover evidence of the participation in or preparation for a crime, like espionage, sabotage, or conspiracy, or will turn up information from a foreign source about the activities, plans, or policies of a foreign government.

A few explanations are in order. First, one will note no mention of collaborators. The term "collaborator" is not easily defined and could be applied to a range of persons, from the spy who is consciously engaged in criminal activities to the descendant of immigrants who, retaining emotional ties with the country of his ancestors, peacefully supports their interests in domestic councils. Domestic political activity in favor of the interests of foreign governments should be subject to no greater inhibitions than other forms of domestic political participation-if the activity is truly "home grown"-and the treatment to be accorded "collaborators" should reflect this judgment. On the other hand, if the individual is an agent of a foreign government, either in law or in fact-and if the magistrate is satisfied that there is probable cause to support this judgment-then he stands in no different position than does a formally accredited foreign official, and those same considerations about the amenability to intelligence operations apply. ${ }^{72}$ And, of course, if there is probable cause to suspect criminal involvement, under any standards a warrant should issue.

Permitting surveillance where there is probable cause to believe that the search will uncover information from a foreign source relating to the plans, activities, and policies of a foreign government represents something of a compromise, and admittedly one subject to question. All students of foreign intelligence agree that much critical information has nothing whatsoever to do with actual or potential crime. The basic negotiating position of a potential adversary, or even of a friend, in international relations is an example. Any standard for the issuance of warrants must take this into account. On the other hand, the fourth amendment plainly should not tolerate the collection by search of all information that may be important for the formulation of foreign policy. A recent newspaper story provides an illustration.

The Washington Post reported ${ }^{73}$ that in 1962, Attorney General Robert F. Kennedy authorized a wiretap on the residence of the chief clerk of the House Agriculture Committee in order, according to the Attorney General's

71. The Constitution protects American citizens and lawfully admitted aliens alike. See Kwong Hai Chew v. Colding, 344 U.S. 590, 596-97, 596 n.5 (1953). See also Au Yi Lau v. United States, 455 F.2d 217, 223, cert. denied, 404 U.S. 864 (1971).

72. See generally' Foreign Agents' Registration Act, 22 U.S.C. $\$ 811-21$ (1970).

73. Washington Post, Dec. 8, 1975, at A1, col. 6 . 
authorizing memorandum, to "keep abreast of activities with regard to pending sugar legislation." Evidently, the White House was concerned about opposition to its plan to cut down on the $\$ 56$-a-ton premium that foreign sugar growers received by selling their sugar in the United States. Assuming the newspaper account to be accurate and complete, legislative action would clearly have had an impact on the nation's foreign policy, just as the positions of members of the foreign affairs committees of either house of Congress have an impact on the nation's policies with regard to issues having a more direct impact on basic questions of war and peace.

But utility of the information in conducting foreign relations cannot be enough. Although we can understand why the White House would like to know what key members of the Senate Foreign Relations Committee are thinking about the executive's SALT negotiations, for example, I hope we would all agree that it would be intolerable to allow the President to resort to either wiretapping or a "black bag" job to find it out. Moreover, our sense of outrage should be no less intense even if such a tactic were to be sanctioned by a "neutral magistrate." Usefulness alone as a test, consequently, cannot justify surveillance of American citizens and domestic institutions for "foreign intelligence," even with a warrant.

Yet, where there is probable cause to believe that a person has information about the plans, activities, or policies of a foreign government, his privacy interests become diluted and may permissibly be balanced against the President's determination that the need to learn the information about the foreign government is of grave national importance. Of course, in most instances, surreptitious efforts will not be needed to acquire the information; typically the American citizen is likely to cooperate in an informal interview. But if that direct approach is either unavailing or ill-advised, surveillance may be justified, at least if the information is derived from some foreign source, such as from contact with foreign officials or businessmen or from foreign travel. This "foreign source" limitation is designed to limit the authority to collect secret intelligence from American citizens whose own conduct is not suspect.

It should be feasible for officials of the executive branch to demonstrate to a magistrate that a proposed intelligence operation will produce information of this nature from a foreign source, if there is, in fact, probable cause to believe that the target has such information. One need not be too concerned about the ability of the magistrate to evaluate the showing, since his function is limited to reviewing the probable source and general nature of the information sought, and he is not re-evaluating the executive's judgment that the information would be worth collecting.

These proposals for basic guidelines under which warrants may issue, tentative and general as they are, are presented primarily for the purpose of 
stimulating discussion. It should be noted that with the possible exception of the guideline concerning searches of individuals having no formal connection with a foreign power, they are quite easy to apply, and indeed, under them, the role of the magistrate, while clearly within his competence to perform, is rather circumscribed. Perhaps most important, in no circumstance would a magistrate be called upon to override the President's assessment of his need for foreign policy-related information. In this connection, it is worth noting that a majority of the $Z$ weibon court, while insisting on a warrant requirement, predicted that a warrant application would rarely, if ever, be refused. ${ }^{74}$

There are other reasons to suppose that, as a practical matter, limitations of judicial expertise will not result in unjustified refusals of warrant applications. First, the Government may present its application to any judicial officer, and there is no reason to suppose that the President will have any difficulty identifying a sympathetic and trustworthy judge. Second, there is nothing to prevent the Government from turning to another judge should the first refuse to authorize the surveillance. ${ }^{75}$ Finally, Congress could designate particular judges-for example, the chief judge of any circuit-to hear warrant requests; indeed, Congress could possibly create a new position solely for this purpose. $^{76}$

\section{In Praise-Albeit Restrained-of Warrants}

As the foregoing demonstrates, the arguments against imposition of a warrant requirement, even in the foreign intelligence area, are not very powerful, provided the role of the issuing officer is properly defined. In fact, it should be expected that such warrants will routinely issue. But if this is the case, why bother? Are there persuasive arguments in favor of a warrant requirement, or is it merely an empty ritual? After all, it might well be argued that, once the substantive standards of the Constitution are defined in this area, either by the courts or even by Congress, reliance on the judgment of the President (or the Attorney General) that the tests are satisfied could be an adequate process in this exceptional area. 1 believe the arguments in favor of a warrant requirement have the edge, but the case should not be overstated.

Initially, it must be conceded that one can imagine a democratic system, fully sensitive to individual privacy and the dangers of undue governmental

74. 516 F.2d at 645,702 . See also United States v. United States Dist. Court, 407 U.S. 297, 320 (1972).

75. See Zweibon v. Mitchell, 516 F.2d at 645 n. 147; $c f .18$ U.S.C. $\$ 2518(1)($ e) (1970) (Applicant for wiretap must provide judge with information concerning previous application).

76. Although the matter has not received definitive consideration, it seems relatively clear that there is a fair degree of flexibility in selecting the official authorized to issue warrants. $C f$. Shadwick v. City of Tampa, 407 U.S. 345 (1972) (court clerk could constitutionally serve as "neutral magistrate"). 
intrusion, where national security surveillances are undertaken without prior judicial authorization; and, of course, such countries actually exist. For example, as then Attorney General Levi emphasized, ${ }^{77}$ in England, West Germany, and Canada, electronic surveillance can be instituted for national security purposes without prior judicial authorization, although various procedures, including pre-search cabinet review and post-search reports to the legislature, act to check unfettered discretion. ${ }^{78}$

Nevertheless, a warrant requirement does have considerable value, particularly in light of our country's political and legal traditions. First, even if the warrant requirement is part ritual, the importance of political ritual should not be overlooked. Particularly when the practical effects of imposing a warrant requirement appear to be minimal, the possibility that the conflict over warrantless searches may be in part a symbolic interbranch battle should not be disregarded. In this respect, it seems appropriate to regard the battle as part of the larger ongoing conflict over executive prerogatives, a battle that has ranged from matters of executive privilege to questions of the breadth of the President's war-making powers. Although this is not the occasion for me to offer my views on these other conflicts, the fact remains that our history has established the warrant requirement both as a protection of individual liberties and as an incident of the scheme of separation of powers contemplated by the Constitution. ${ }^{79}$ This fact alone might not justify imposition of the warrant requirement if it were otherwise inappropriate, but it does establish something of a presumption in favor of its use.

Second, a warrant requirement ensures accountability. Although the background processing will rarely have to be revealed, the identity of the officials requesting and approving the search and their reasons therefor will be made part of a court record. I suspect that nothing deters improper official conduct more effectively than the knowledge that the official must leave his tracks in records that may not be forever secret, and that he may one day be forced to give a public account of his actions as reflected in that contemporaneous record. ${ }^{80}$ Accountability requires at least minimal record-keeping. ${ }^{81}$ Indeed, it

77. Testimony of Attorney General Levi, supra note 44, at 58-60.

78. See, e.g., Washington Post, Dec. 22, 1975, at A 1, col. 5; Al1, col. 1, for an account of the British approach, which involves detailed review by the British Home Secretary of a request to conduct such an operation. The Home Secretary is advised on these requests by a cautious group referred to as the "old ladies." According to the Washington Post, Dec. 24, 1975, at Al, col. 3, the French intelligence gathering operation is a good deal more free-wheeling

79. See United States v. United States Dist. Court, 407 U.S. at 318.

80. I cannot help referring to the "Nixon tapes," which turned out to be the former President's downfall when the Supreme Court held that he could not conceal the recordings of his actions. United States v. Nixon, 418 U.S. 683 (1974).

81. A good example concerns the various taps on the phones of Rev. Martin Luther King, Jr. No one living has a very good recollection about the circumstances surrounding the authorizations for the taps, which seem to have been processed mainly by oral requests and briefings. See, 
was this same sense of the importance of fixing accountability that led a unanimous Supreme Court to hold the officials of the Justice Department to strict adherence with the provisions of the federal wiretap statute governing the internal processing of wiretap applications in ordinary criminal investigations. ${ }^{82}$ A warrant requirement would ensure that, in addition to Justice Department files, there would be permanent records virtually immune to tampering that would prevent a total evasion of responsibility.

Third, and perhaps most important, the requirement that the Government present its case for a search to a detached officer-by our constitutional tradition, a judicial officer-forces the President or his delegate to articulate the reasons for the proposed search in language that will be convincing beyond the circle of the President's immediate advisors. As anyone who has been forced to translate general apprehensions into reasoned arguments knows, that very process stimulates thought and re-evaluation of formerly unquestioned premises. It is conceivable, though one should not indulge in wishful thinking, that the necessity for engaging in this type of exercise will serve to screen out requests that should not in good conscience be made. The discipline that flows from having to justify one's position to a third party can serve a purpose that is perhaps as important in guarding against abuses as is the judgment of the magistrate himself.

Of course, there may, indeed, be cases in which the warrant request is so outlandish that it will be denied. It would be naive, however, to be sanguine about this prospect, for even groundless searches, or those taken for purposes that can only be deemed malign, can be camouflaged by artful pleading. A good case in point is the burglary of the office of Dr. Lewis J. Fielding, the psychiatrist of Daniel Ellsberg. I suspect that, under the guise of searching for national defense secrets that may have been disclosed to the psychiatrist or of seeking the identity of foreign agents with whom Ellsberg may have been in contact, the White House probably could have secured a warrant placing the agents in a position to look for the derogatory psychological information that was really sought for political reasons.

\section{VI}

\section{The Limits of Judicial Power}

It would appear that on balance, a warrant requirement could only be beneficial. But it would be an error to assume that a warrant requirement would go very far in securing domestic liberty and preventing the types of

\footnotetext{
e.g., the account of former Attorney General Katzenbach, as reported in the Washington Post, Dec. 4, 1975, at Al, col. 7; Al6, col. 1. And dead men, as is well known, tell no tales.

82. See United States v. Giordano, 416 U.S. 505 (1974) (interpreting Title III of the Omnibus Crime Control and Safe Streets Act of 1968, 18 U.S.C. $\$ 2510$ (1970)).
} 
abuses mentioned at the outset of this discussion. Given the necessarily circumscribed role of the magistrate described above, it seems clear that we cannot rely primarily upon the judiciary for the development of the law in the area of foreign intelligence searches. Indeed, as to national security searches generally, as Judge Goldberg noted in a concurring opinion in United States $\%$. Brown, ${ }^{83}$ the development of the law is impeded by the fact that the factual predicates of judicial decisions cannot be revealed and that individual judges must often act in ignorance of related decisions by their colleagues. Thus, if workable standards are to be developed-and the development of the law is the process by which general principles become particularized-the responsibility will fall in large part on the Congress and upon the executive branch.

Congress faces a good deal of unfinished business in this area. To begin with, it must decide whether the procedures governing the issuance of search warrants enumerated in Title III of the Omnibus Crime Control and Safe Streets Act of $1968^{84}$ apply to warrants for national security searches. The question was not decided in the "Keith" case, and it badly split the Zweibon court. Without going into detail, several of Title III's procedural requirements-for example, the requirement that parties subjected to surveillance eventually be notified of that fact-are clearly unsuited to many types of foreign intelligence operations and perhaps to some kinds of domestic security activities as well; but congressional intent as to this question is far from clear. By simple amendment, Congress could make its intentions known.

Recently, then Attorney General Levi invited the Congress to develop a statutory base for a new kind of warrant, ${ }^{85}$ perhaps along the lines discussed in this paper, for national security searches. His successor, Attorney General Griffin Bell, has put the new Administration on record as supporting legislation in this sensitive area. ${ }^{86}$ Congress should definitely begin the attempt. It should be pointed out, however, that as desirable as that enterprise may be, Congress does not have an entirely free hand in circumscribing national security intelligence gathering. To the extent the President's authority to gather intelligence under certain conditions is an incident of his indivisible power to guide the nation's foreign relations and to serve as commander-in-chief of our military forces, unduly restrictive legislation might violate separation-of-powers principles and impinge upon his constitutional prerogatives. ${ }^{87}$ But the issue

83. 484 F.2d 418,427 (5th Cir. 1973).

84. 18 U.S.C. $\$ 2510(1970)$.

85. Testimony of Attorney General Levi, supra note 44, at 50.

86. See Statement of the Honorable Griffin B. Bell, Attorney General of the United States, before the Senate Judiciary Comm. Subcomm. on Criminal Laws and Procedures on "The Foreign Intelligence Surveillance Act-S.1566," submitted June 13, 1977.

87. In Butenko, Judge Gibbons, in a scholarly dissenting opinion, discussed the English antecedents of the nation's foreign affairs power and concluded that the Constitution deliberately distributed what had been the King's prerogatives partially to the President and partially to the 
is far from clear, and Congress should accept the Attorney General's invitations and attempt to import some clarity into this area of the law.

\section{Conclusion}

In the last analysis, however, rules, procedures, and guidelines, though indispensable, do not substitute for the love of liberty. We like to say we have a government of laws, not of men. But this nice aphorism is a gross oversimplification. As Watergate has shown us, laws do not guarantee decent behavior from our public servants. In a democracy especially, there is no substitute for officials of honor and integrity who appreciate our constitutional ideals, and do not resent them as shackles on their ability to preserve our "national security." More than any other official, the President sets the tone for the Government. He and his subordinates in the executive branch possess extraordinary power to gather secret intelligence. In the long run, the most effective limits on that power are likely to come from the President's own sense of restraint and his appreciation of the principle that we must not sacrifice our way of life in trying to protect it. ${ }^{88}$

Congress. From this he reasoned that since the power to conduct the nation's foreign affairs was shared, Congress, no less than the President, may govern the way it is to be exercised. See 494 F.2d 593, 626-37 (3d Cir. 1974) (Gibbons, J., dissenting). Judge Aldisert, however, took a contrary view. 494 F.2d at 622-23 (Aldisert, J., concurring and dissenting), 494 F.2d at $61 \mathrm{l}$ (Sietz, C.J., concurring and dissenting), and the holding of the majority did not require it to face the issue. A similar thesis of shared responsibility is expressed in A. Sofaer. War Foreign Affairs and Constitutional Power: The Origins (1976).

88. The hearings before the Ervin Committee several years ago vividly illustrated the consequences of high level insensitivity to these values. Under examination by Senator Talmadge, John D. Ehrlichman, formerly counsellor and chief domestic advisor to President Nixon and in the interim convicted for his role in the break-in at Daniel Ellsberg's psychiatrist's office, testified that he believed the President had the inherent legal authority to order warrantless break-ins in the name of "national security." When asked if that power would include the commission of a murder or other crimes for the same objective, Ehrlichman replied: "I do not know where the line is, Senator." When testimony returned to the break-in, the following colloquy took place:

Senator Talmadge: Do you remember when we were in law school, we studied a famous principle of law that came from England and also is well known in this country, that no matter how humble a man's cottage is, that even the King of England cannot enter without his consent.

Mr. Ehrlichman: I am afraid that has been considerably eroded over the years, has it not?

Senator Talmadge: Down in my country we still think it is a pretty legitimate principle of law. [Applause].

6 Hearings Before the Senate Select Comm. on Presidential Campaign Actinties, 93d Cong., 1st Sess. 2600-01 (1973).

In the recent televised interviews of former President Nixon by David Frost, the ex-President resolutely insisted:

"It's quite obvious that there are certain inherently governmental activities, which if undertaken by the sovereign in protection of the interests of the nation's security are lawful, but which if undertaken by private persons are not."

"The Nixon Interviews with David Frost: Program 3" broadcast May 19, 1977, tr. p. 56. 
The activities of Government discussed in this paper are by their nature secret. Particularly if the goal of surveillance is gathering long-range intelligence rather than evidence for a criminal prosecution, warrant requirements can be easily evaded, and guidelines easily ignored. For these problems, there is no easy solution. Ultimately, our liberty depends not so much on how we define the abstract rights and prerogatives of the President in gathering intelligence, but on the vigor with which we insist that our governors are faithful to the shared ideals of a free society and on the strength of our common commitment to individual liberty as an indispensable element of true national security. 